\title{
Modernidad última en América Latina y posturas de la crítica artística
}

\section{Late Modernism in Latin America and Positions of the Art Criticism}

José Luis de la Nuez

Universidad Carlos III, España

nogal@hum.uc3m.es

\section{Resumen}

Este estudio se propone confrontar distintos posicionamientos de la crítica artística latinoamericana de la segunda mitad del siglo XX en relación con las nuevas vanguardias que se difunden desde Europa y los Estados Unidos. La llegada del arte concreto, el informalismo, el pop y otros movimientos artísticos generó una respuesta crítica que en unos casos cuestiona las interpretaciones metropolitanas mientras que en otros parece asumirlos. Al contrastar los puntos de vista de los críticos elegidos (Mário Pedrosa, Jorge Romero Brest y Marta Traba) nos encontramos con coincidencias y disidencias entre ellos que son elocuentes de la disparidad de criterios y la diversidad de expectativas que en estos momentos existen en el terreno de la cultura artística latinoamericana.

Palabras clave: crítica de arte, modernidad, vanguardia, arte concreto, informalismo, arte pop, happening, Mário Pedrosa, Jorge Romero Brest, Marta Traba.

\section{Abstract}

This study proposes to confront different positions of Latin American art criticism in the second half of the twentieth century regarding to the new vanguards that spread from Europe and the United States. The arrival of concrete art, the informalism, pop art and other artistic movements generated a critical position which in some cases questions the metropolitan interpretations while others seem to assume them. When contrasting the points of view of critics selected (Mário Pedrosa, Jorge Romero Brest y Marta Traba) we find similarities and disagreements among them which demonstrate the difference of opinions and diversity of expectations that exist at those moments in the realm of Latin American artistic culture.

Keywords: Art Criticism, Modernity, Vanguard, Concrete Art, Informalism, Pop Art, Happening, Mário Pedrosa, Jorge Romero Brest, Marta Traba. 
Las complejas relaciones existentes entre el arte latinoamericano y los centros hegemónicos dinamizadores del arte contemporáneo han generado un debate importante del que se han hecho eco la crítica y la historia del arte del subcontinente a lo largo del siglo $\mathrm{XX}$. Es cierto que la naturaleza de este debate se vio muy alterada como consecuencia de la irrupción del pensamiento postmoderno y el cuestionamiento de las visiones lineales y totalizantes de la historiografía moderna, pero incluso en las décadas en las que esta impuso su visión exclusiva del acontecer artístico encontramos diferencias significativas en los análisis que se hicieron desde América Latina con respecto a este asunto. Cabría entender esto en dos niveles de aproximación: por un lado tendríamos la diversidad del juicio crítico desde América Latina sobre los lenguajes artísticos tal como se manifiestan en origen, por otro, cómo se interpreta la repercusión que estos tienen en el territorio latinoamericano, cuál es la consideración de los cambios que conlleva su aclimatación a un entorno social y cultural radicalmente distinto; en fin, la valoración que este fenómeno merece en la construcción del relato histórico-artístico que va conformando la fisonomía cultural de los distintos países.

Nos interesa indagar aquí en las respuestas críticas suscitadas por las distintas tendencias que irrumpieron en América Latina en la segunda mitad del siglo XX. Se da la circunstancia de que la llegada de estas tendencias a este espacio cultural coincide con la consolidación de una nueva crítica, cuyo perfil profesional tiene pocos precedentes en las primeras décadas del siglo XX. Nos referimos a una crítica artística formada en el ámbito universitario ${ }^{1}$, con buenos fundamentos metodológicos, que además conoce de primera mano el arte contemporáneo de Europa y Estados Unidos porque viaja con regularidad. Fenómenos como la creación de la Bienal de São Paulo o la aparición de nuevos museos de arte contemporáneo no van sino a fortalecer su presencia y su capacidad de influencia. Pues bien, va a ser esta crítica la que asuma la responsabilidad de definir lo que podemos considerar como una interpretación local del arte moderno último frente al discurso emanado de Europa o los Estados Unidos, cargado de autoridad legitimadora.

Tres autores nos parecen bien representativos de los distintos posicionamientos de la crítica en este contexto: el brasileño Mário Pedrosa y los argentinos Jorge Romero Brest y Marta Traba. Las aportaciones de los tres se inscriben en una visión moderna de la realidad artística, pero también son muy reveladoras del contraste de criterios existente a la hora de abordar el panorama artístico que se va conformando en las décadas que siguen al final de la Segunda Guerra Mundial en América Latina. Los tres tuvieron experiencia docente en el mundo universitario y llegaron a dirigir instituciones museísticas, los tres, en fin, ejercieron la crítica en medios muy diversos. El legado bibliográfico que nos han dejado es imponente. Por supuesto,

1 Sobre la influencia del mundo universitario en la formación de la crítica de este periodo, vid. Agustín Martínez, Agustín. Crítica de la Cultura en América Latina. Caracas: Fondo Editorial Tropykos, 1991. 
no es nuestro objetivo analizar en profundidad la aportación de cada uno de ellos, algo que desborda con mucho los límites de este texto; pero sí fijar cuáles son sus principales líneas de pensamiento con relación a las nuevas vanguardias que llegan al territorio latinoamericano en este periodo. Antes trataremos de desvelar cuáles son las inflexiones que podemos reconocer en su pensamiento artístico con respecto al juego de relaciones que se establece con la crítica extranjera, su grado de tolerancia o insubordinación frente a lo que frecuentemente se vive (no siempre) como imposición de valores y gustos.

Conocida es la postura política de Mário Pedrosa ${ }^{2}$ y lo determinante que fue en su biografía, considerando además el difícil contexto brasileño que le tocó vivir. Sacamos a colación este aspecto de su vida porque no puede desligarse de su actividad como crítico. Como es sabido, su identificación con el trotskismo lo ubica en una posición diferenciada con respecto a otros intelectuales marxistas de su época, y si queremos señalar cuál es su actitud frente a los modelos artísticos foráneos sería bueno empezar por su desmarque frente al realismo socialista impulsado por el estalinismo. En su Vicisitudes del artista soviético, Pedrosa califica al realismo socialista de "estética burocrático-burguesa, com uma função social muito precisa de idealização da nada atraente realidade social dada" (94). Frente a las olvidadas manifestaciones del constructivismo de los primeros años de la revolución (ahora en los fondos de los museos de la URSS, sin posibilidad de recuperación alguna) se alzaba el pintor oficial que retrata al héroe positivo en postura grandilocuente. Así como Napoleón tuvo a su Meissonier, aclara Pedrosa, Stalin contó con Guarassimov. Los paralelismos históricos son bien demostrativos de la postura del crítico, que resalta además cuál era la opinión de Trotsky, seguidor del constructivismo y firme partidario de la fusión entre arte y vida. En un texto escrito dos años después, el crítico brasileño sacará a relucir nuevamente el asunto de las relaciones entre revolución política y revolución artística, concluyendo que esta última debía entenderse sobre todo como revolución de la sensibilidad, una revolución a la que estaba contribuyendo en gran medida la difusión de la plástica abstracta. La revolución de la sensibilidad sería de todas ellas la más profunda y permanente, "e não serão os políticos, mesmos os atualmente mais radicais, nem os burocratas do Estado que irão realizá-la. Confundir revolução política e revolução artística é, pois, um primarismo ben típico da mentalidade totalitária dominante" (Arte e revolução 247).

El antiimperialismo de Pedrosa, uno de los grandes argumentos de su ideario político, tuvo también su reflejo en el juicio crítico. No faltaron ocasiones en las que puso de manifiesto su profundo rechazo a la mirada condescendiente, llena de prejuicios, del arte metropolitano hacia la creación artística latinoamericana o brasileña.

2 Texto clave para entender la posición política de Mário Pedrosa es A opção brasileira. Río de Janeiro: Editôra Civilição Brasileira, 1966. 
Ya en 1954 expresaba este malestar, lamentando esa tendencia tan frecuente en la cultura occidental a identificar la plástica latinoamericana con expresiones nacionales de tipo "primitivo". Al contrario, habría que valorar en qué modo lo mejor de esta plástica se manifestaba como una extensión mejorada de Occidente, de manera que "perdem cada vez mais o antigo complexo colonial (ainda dominante nas gerações mais velhas) para com a mãe-patria européia e se consideram, com razão ou sem ela, como os portadores da tocha olímpica da velha cultura renovada; em suma, do seu futuro" (Bienal, panorama do mundo 194). Unos años después, con ocasión de la celebración de la IV Bienal de São Paulo (1957), en un artículo en Jornal do Brasil, nuevamente Pedrosa mostraba su malestar por la actitud indulgente e interesada de los críticos europeos y norteamericanos, que no valoran realmente la singularidad de la aportación a la modernidad del arte brasileño y demandan más bien un arte dentro de los esquemas del exotismo: "Entendem, porém, por autóctone tudo que indique primitivismo, romantismo, selvagismo, isto é, no fundo, exotismo. Não gostam de permitir aos nossos artistas uma pesquisa, uma linguagem moderna e não ao gosto do momento nos grandes centros europeus" (O Brasil na IV Bienal 279). He aquí, por tanto, una posición claramente definida que reivindica la especificidad del arte latinoamericano en su concreción moderna y rechaza la imagen de lo exótico como estereotipo excluyente que se le quiere atribuir. Pedrosa se situaba así como un adelantado de unos planteamientos que serán asumidos de manera generalizada por la crítica latinoamericana del último tercio del siglo XX.

¿Podríamos encontrar una actitud parecida a la de Mário Pedrosa en el caso de Jorge Romero Brest? No lo parece, a juzgar por sus escritos y su postura como gestor cultural durante décadas en Buenos Aires. A decir verdad, Romero Brest se comporta y piensa como un crítico occidental trasplantado a suelo americano. El libro que escribe en 1952, La pintura europea contemporánea 1900-1950, señala muy claramente cuál es la prioridad de sus intereses en el campo de la historia del arte contemporáneo. No sufre la humillación que denuncia Pedrosa, porque se reconoce entre iguales cuando debate con los críticos europeos o norteamericanos. Desde luego, no cabe la menor duda de que Romero Brest persiguió denodadamente, desde sus responsabilidades múltiples en el sistema artístico argentino, la difusión y el reconocimiento del arte de su país en la esfera internacional, su legitimación en diálogo con la "mainstream". Sin embargo, dependió siempre de la opinión de otros, en Europa o los Estados Unidos, para hacer factible ese reconocimiento. Así, cuando en su libro El arte en la Argentina explica el éxito internacional de la abstracción concreta nos recuerda cómo fue Max Bill quien le confirmó "que después del grupo dirigido por él, en Zúrich, sobresalía netamente el de Buenos Aires" (35). Durante los años que dirigió el Centro de Artes Visuales del Instituto Torcuato di Tella se rodeó de críticos internacionales como miembros del jurado que otorgaba los premios anuales (Venturi, Argan, Sweeney, entre otros). El resultado fue, según confesión propia en el libro citado anteriormente, que la crítica internacional descubrió Buenos Aires, y hasta Pierre Restany 
llegó a vislumbrar un próximo Buenos Aires como gran centro de arte internacional, siguiendo la estela neoyorquina. En términos parecidos se llegó a expresar Lawrence Alloway. La preocupación identitaria no existe en la teoría artística de Romero Brest hasta los setenta, y un tanto a remolque del gran debate que se está generando en esos momentos en la crítica latinoamericana, encabezado por Marta Traba.

Con Marta Traba retomamos el discurso crítico de confrontación que se puede ver en los escritos de Mário Pedrosa, si bien en el caso de aquella estamos ante una apuesta con vocación decididamente latinoamericanista. Con Traba el debate sobre el papel del arte latinoamericano en el escenario internacional adquiere una dimensión que no tiene precedentes en la cultura artística del subcontinente. No hablamos aquí, como tampoco lo hicimos con los otros dos autores citados, de determinadas propuestas plásticas; sí nos interesa, sin embargo, destacar cómo se explicita en sus textos las divergencias o sus desacuerdos con respecto a los modelos artísticos centrales que actúan como referencias para el artista latinoamericano. En sus libros de la década de los setenta se configura en gran medida lo esencial de su postura crítica con respecto a este asunto. Así, en Arte latinoamericano actual daba la voz de alarma sobre la carga de dependencia mostrada por la vanguardia latinoamericana en esos momentos, pues "está trabajando en artes plásticas de acuerdo con la señal impartida desde Norteamérica” (21). Desde esta perspectiva, actuaciones como las promovidas por Jorge Romero Brest desde el Centro de Artes Visuales del Instituto Di Tella, algo que se había interpretado como el intento de conformar una "coalición de culturas" entre América Latina y los países centrales, resultaba un fracaso, en su opinión, por su asimetría. Es más, suponía “una abdicación inexcusable al intento - no importa si sea fallido o no- de formulación de un lenguaje propio" (15). Se deducía de estas palabras que en el discurso Traba se perfilaba una opción para el arte latinoamericano que pasaba por el reconocimiento de sus peculiaridades a partir de su confrontación con los modelos foráneos invasivos, lo que ella llamó, en definitiva, arte de la resistencia ${ }^{3}$. En su obra más importante, Dos décadas vulnerables en las artes plásticas latinoamericanas (1950-1970), la autora argentina explicaba que la falta de un proyecto propio para el arte latinoamericano contemporáneo era debida en gran medida a que este había seguido fielmente una concepción del tiempo y del espacio que le era ajeno, pues provenía del ámbito europeo y norteamericano: "Entre las preocupaciones físicas o metafísicas de los que, en los Ismos europeos, buscaban el movimiento y las diversiones concretas de los americanos y europeos actuales, los latinoamericanos se han visto violentados a aceptar una categoría que parece ir a contrario sensus de su propia naturaleza" (19).

3 Vid. Traba, Marta. “Arte de la resistencia”. ECO: Revista de la Cultura de Occidente 181 (1975). 95-99. 


\section{Una herencia de las vanguardias históricas: el arte concreto.}

La abstracción geométrica y más específicamente el arte concreto, fue un asunto central en la crítica de Mário Pedrosa y Jorge Romero Brest durante la década de los cincuenta, si bien lo que fue inicialmente una coincidencia en los juicios valorativos se mostró más adelante con resultados teóricos diferentes. En la primera mitad de la década se define en gran medida la postura de Romero Brest con respecto a esta tendencia ${ }^{4}$. En un artículo escrito para la revista Saber Vivir, en 1954, esbozaba un panorama del arte contemporáneo en el que el arte concreto se mostraba como una opción superior frente al arte representativo, "cada vez más anacrónico", y a la abstracción no geométrica, una orientación plástica con la que resultaba muy difícil conseguir una expresión universal. Lo realizado hasta ahora por el arte concreto lo entendía más bien como experiencias, "mientras sigan sujetos al cuadro los pintores y a la estatua los escultores", pero su desarrollo "podrá proporcionar el lenguaje del siglo" (Diálogo sobre el arte abstracto 24). La dimensión utópica del arte concreto defendida por Romero no era otra que la de los constructivistas del periodo de entreguerras, firmes partidarios de la superación del objeto artístico tradicional y de la integración del arte en la arquitectura. El año antes, en el catálogo de la exposición en la que se habían mostrado obras de los concretos argentinos en Río de Janeiro, el crítico explicaba la abstracción de estos como un paso más, definitivo, en el camino "que conduz ao descobrimento duma nova objetividade, a única que não responde à realidade circunstanciada do homem sensível e sentimental que se concebe como indivíduo, a única que implica a superação da contingencia: a geometría" (Um grupo de jovens pintores e escultores argentinos 6-7). Frente a ello, lo que Romero denomina “dirección romántica del arte abstracto”. En su libro ¿Qué es el arte abstracto?, explicaba cómo siendo esta vertiente de la abstracción totalmente legítima, los artistas que la practican "no proporciona ninguna solución al problema del arte y que al detenerse en la subjetividad no hallan el modo de objetivarla” (59). Por tanto, debe entenderse su apuesta por el arte concreto como la elección de una opción cargada de razones utópicas y positivas en un contexto artístico internacional, sin embargo, donde se iba a imponer cada vez con mayor fuerza la abstracción informalista. Finalmente, su experiencia en el ámbito argentino como impulsor de esta corriente se saldó de manera frustrante por la desvitalización del movimiento, pese a los reconocimientos internacionales, como él mismo resaltó en su momento (El arte en la Argentina 36). No obstante, de la experiencia del concretismo persiste en la teoría crítica posterior de Romero Brest una línea argumental fundamental que es aquella que apunta hacia el cuestionamiento del objeto artístico tradicional.

4 En su libro La pintura europea contemporánea (México: FCE, 1952) Romero Brest deja buena muestra de la importancia que le concede a esta vertiente de la abstracción, que estuvo también en el debate de la revista Ver $y$ Estimar, dirigida por él. Vid. Giunta, Andrea y Malosetti, Laura (comps.). Arte de posguerra: Jorge Romero Brest y la resvista Ver y Estimar. Buenos Aires: Paidós, 2005. 
Las preferencias de Mário Pedrosa por el arte abstracto geométrico están muy presente es sus textos de los cincuenta, y puestos a encontrar coincidencias con Romero Brest $^{5}$, podemos señalar que ambos participaron del mismo entusiasmo por el suizo Max Bill, cuyas obras causaron un gran impacto en los círculos artísticos brasileños de principio de la década. Hay también planteamientos muy similares en la defensa de un proyecto utópico basado en la obra de estos artistas que se interesan por un arte de construcción. Para el crítico brasileño, este arte "possa dar à nossa época a homogeneidade espiritual que lhe falta, quer dizer, as formas mais essenciais, mais gerais e mais afetadas de uma simbólica realmente universal (...) É uma arte resolutamente otimista que procura definir o estilo da época" (Bienal, panorama do mundo 195). Sin embargo, el análisis de los escritos de Pedrosa revela también una dirección propia en sus elaboraciones teóricas, una impronta cada vez más personal que guarda una estrecha relación con la evolución de la vanguardia brasileña que había tenido su origen precisamente en el arte concreto. En la formación intelectual de Mário Pedrosa fue muy determinante su pasión por la política en clave transformadora, pero también su interés por la psicología del arte y la psicología de la percepción, aspectos estos que lo diferencian de Romero Brest. Pronto empezó a plantear la defensa del arte concreto brasileño en una dirección reivindicativa, como una opción propia frente a las tendencias dominantes en el exterior. Lamentaba Pedrosa, precisamente, el desconcierto de algunos críticos internacionales, incluso su irritación, como se había visto en la IV edición de la Bienal de São Paulo, ante el rumbo que estaba tomando el arte más vanguardista en Brasil, tan alejado del gusto predominante en los centros hegemónicos:

Predomina agora nesses centros uma arte de tendência romântica, o melhor, anticultural, no sentido de preferir os valores ditos instintivos ou subjetivos aos valores plásticos mais puros. Têm horror, como homens cansados de cultura e de experiências estéticas, a tudo que lembre strutura, ordem, disciplina, tensões, otimismo, beleza plástica, em suma. Ora, os nossos melhores artistas de agora não estão nessa linha, pior ainda: não se importam se o que atualmente estão fazendo, não é o que está em moda na Europa ou los Estados Unidos (O Brasil na IV Bienal 280).

Pedrosa entendía el concretismo y, luego su derivación, el arte neoconcreto, como un ejercicio de experimentación libre y a la vez como una apuesta ética. En los años sesenta, a la vez que se va definiendo la obra de artistas neoconcretos como Lygia Clark, Oiticica o Lygia Pape, el crítico desarrolla un discurso teórico cada vez más alejado de la pureza del concretismo. La oportunidad del arte neoconcreto ${ }^{6}$ le per-

5 A propósito de las relaciones entre Jorge Romero Brest y el arte y la crítica brasileñas, vid. García, María Amalia. «Entre Mário de Andrade y Mário Pedrosa: Jorge Romero Brest y la crítica de arte en Brasil». Figuraciones 10 (2012). Sitio Web. Fecha de ingreso: 12 de mayo de 2013.

6 El neoconcretismo suponía, como lo dejó bien claro en su Manifiesto Neoconcreto (1959) el poeta Ferreira Gullar, un salto cualitativo con respecto al concretismo, al que se atribuía un excesivo racionalismo y una incapacidad para ahondar en una expresividad más abierta. También se aborda ahora, desde estos nuevos presupuestos, una revisión del legado del constructivismo histórico. 
mitía incidir en valores despreciados por los concretistas, como el subjetivismo y la interacción con el espectador, buscando su implicación.

En su primer libro dedicado al arte latinoamericano, La pintura nueva en Latinoamérica, Marta Traba puso de manifiesto una opinión sobre la abstracción geométrica argentina muy discordante con las manifestadas por Romero Brest y Pedrosa a propósito del arte concreto. El juicio de Traba, severo, poco condescendiente, guardaba ciertas similitudes con las críticas más refractarias que en España se habían podido leer en las primeras décadas de la postguerra sobre el mismo asunto. En definitiva, Traba veía en la abstracción geométrica una ausencia de la huella humana que reducía toda esta producción artística a un puro formalismo: "Si el talento creador se elimina y el hombre desaparece detrás del cuadro, no dejando huella alguna de su presencia, el arte pierde su condición más heroica, su condición humana y queda relegado a puro formalismo" (112). Parece obvio, por lo que se lee, que a Traba no le resultaban convincentes las elaboradas elucubraciones en torno a este tema que Romero Brest se había preocupado por difundir. Para ella, en fin, "el mejor formalismo argentino es de una irritante perfección". Es más, aconsejaba a estos artistas que se dejaran influir por "las energías tremendas y desatadas" (113) de un De Kooning, un Kline o un Appel, entre otros, una propuesta muy reveladora de la dirección de sus intereses en esos momentos ${ }^{7}$.

\section{Informalismo y neofiguración}

Ni el informalismo ni la neofiguración despertaron en Romero Brest una atención especial en sus trabajos como crítico. Como se puede ver también en el caso de Mário Pedrosa, las preferencias tan marcadas por la abstracción geométrica eran difícilmente conciliables con el irracionalismo informalista. Por otro lado, no fue esta una tendencia con mucha fortuna en la Argentina. De manera que tanto en el caso de Romero Brest como en el de Pedrosa, lo que se escribe sobre informalismo es, en gran medida, aunque no siempre, con la mirada puesta en el panorama internacional. En un texto de 1961, el autor argentino confesaba que resultaba imposible elaborar una teoría del informalismo porque lo impedía la propia naturaleza de esta tendencia. Lo que se constataba de verdad en la obra de los artistas informalistas era una desconsideración total hacia el pasado, a la vez que una desvinculación radical de la idea de "obra de arte": "Un cuadro de Picasso o de Klee o de Vantongerloo, siguen siendo tan obra de arte como un Masaccio o de Velázquez (...) Mientras los pintores que hoy se llaman informalistas y aunque no se llamen así, quieren estar en lo real, huyendo de la forma perenne que constituye la 'obra de arte"' (Sobre el arte informal 9).

7 Todo ello no obsta para que en sus libros posteriores Traba reconsiderara algunos de estos planteamientos negativos y mostrara una posición más receptiva sobre este tema. Esto parece muy evidente en su último texto, Arte de América Latina 1900-1980, editado después de su muerte por el Banco Interamericano de Desarrollo (1995). 
Aseguraba Romero que no había arte más realista que el informalismo por su apego a lo real a través de los materiales; de modo que los artistas que preferían llamarse neofigurativos, como los argentinos Noé o Macció, no se alejaban esencialmente de aquel, pese a la recuperación de las formas humanas que podía verse en sus pinturas: "Cuando miro estas obras se me presentan imágenes existentes del mismo modo que cuando miro obras informalistas, libres de experiencias, ideas, sentimientos o deseos conocidos" (Deira, Macció, Noé, de la Vega 3).

En los textos de Mário Pedrosa de finales de los cincuenta encontramos un acercamiento poco entusiasta al informalismo, que es juzgado más bien como una tendencia superficial, toda vez que los resultados pictóricos que se podían identificar con ella se quedaban en mera proyección o desahogo afectivo sobre la tela. A su juicio, los informalistas no completaban el proceso de la creación artística en su totalidad, esto es, no iban más allá del momento proyectivo inicial, se desinteresaban por el proceso siguiente, en el que se simplifica y cristaliza la expresión y se consigue una plenitud. Pedrosa entendía el informalismo como una manifestación antiartística que había que ubicar en el contexto de la crisis que recorría la cultura contemporánea: "observo fenômeno de ordem geral, que ultrapassa o campo delimitado da Arte ou da crítica, e, profundamente característico de nossa atualidade, é provavelmente, reflexo de proclamada crise dos valores da civilização vigente" (Da abstração a auto-expressão 38). Por otra parte, el informalismo suponía un redescubrimiento de la tela, del soporte tradicional, "depósito de suas ânsias expressivas", en flagrante contradicción con la dirección iniciada por la vanguardia constructivista. Es por ello que, en otro texto, critica la rendición incondicional que para él supone la evolución del italiano Burri, figura sobresaliente del informalismo internacional que acaba "preso à estética do cavalete", pese a sus conocidas experimentaciones matéricas. La postura desdeñosa de Pedrosa frente a la obra de Burri no solamente se explicaba por la incoherencia de su evolución plástica; también porque en las obras del artista italiano se podía constatar hasta qué punto el informalismo había sido deglutido por un mercado ansioso de novedades que estaba al servicio de "consumidores de arte, luxo e uísque do Ocidente" (Burri, ou a antipintura vitoriosa 247).

Una mirada distinta es la que transmite Traba sobre el informalismo y la neofiguración, que se constituye, paradójicamente, en su apuesta alternativa cuando defiende la necesidad de una plástica propiamente latinoamericana. A Traba le interesaba del informalismo no tanto sus experiencias matéricas como lo que ella llamaba "un estado de conciencia", esto es, esa "traducción tan viva y descarnada de una modalidad humana; de un humor inofensivo o sombrío; de una capacidad hacia la grandeza y la heroicidad o de tanteos mezquinos" (La pintura nueva en Latinoamérica 111). Con todo, los análisis retrospectivos que realiza sobre esta tendencia ponen de manifiesto su decepción por la deriva hacia un amaneramiento insoportable y la excesiva complacencia en el trabajo con los materiales (Los cuatros monstruos cardinales 39). En Dos décadas vulnerables, la autora argentina le concede cierta im- 
portancia a la influencia que el informalismo español ejerció en América Latina, pero no ve en sus equivalentes continentales resultados comparables: "Al lado de una obra tan significativa como la de Tàpies resalta sin atenuantes el truquismo informalista de los latinoamericanos" (66).

Por otra parte, Traba emplea el término neofiguración de manera un tanto difusa, pero le sirve para certificar la existencia de un cambio de rumbo en la plástica latinoamericana, que se autoafirma frente a los modelos importados del «pop», el arte cinético, el «happening», etc. En el panorama complejo de los cincuenta y sesenta, se trataba de reubicar la posición del artista latinoamericano, buscando una autenticidad (una postura resistente) que solamente podría lograrse si abandonaba las prácticas miméticas en deuda con los modelos centrales y establecía el conveniente nexo con los anhelos de su comunidad, "cualquiera sea la desesperación, la peligrosidad o la vehemencia de dichos anhelos" (Arte latinoamericano actual 58). Las obras latinoamericanas, por tanto, debían responder a una exigencia de significación auténtica. No se trataba de un anhelo utópico, pues "la violencia independiente con que, en uno y otros países, ha aparecido la neofiguración, es un síntoma muy importante" (59). En esa neofiguración, la recuperación del dibujo jugaba un papel fundamental, como se constataba en la obra del mexicano José Luis Cuevas, uno de los artistas preferidos de Traba. En cualquier caso, como ya había advertido con anterioridad (Los cuatros monstruos cardinales), la apuesta por un arte en el que se plasmase una nueva imagen del hombre solamente podía entenderse como una tarea de pintores solitarios, una vez fracasadas las vías del realismo socialista y el de la "pintura testimonio", representada de manera patética por Bernard Buffet.

\section{Arte pop}

Por lo que se refiere al arte pop encontramos una coincidencia en las reflexiones que aportan Marta Traba y Mário Pedrosa. Ambos compartían una opinión muy despectiva sobre esta tendencia, relacionaban su lenguaje característico con la sociedad de consumo estadounidense en su vertiente más alienante, subrayaban su condición de anti arte, así como su difícil adaptación al medio artístico latinoamericano. En realidad, la condena de Marta Traba hacia el arte pop se extendía a todas las neovanguardias norteamericanas de los sesenta. Tendencias como el "minimal art" o los "happenings" provenían también de un "ámbito estético que, regido por el deterioro y predeterminado por las leyes ideológicas y económicas de la sociedad de consumo, convierte el arte en un compartimento estanco, lo condena a la marginalidad forzosa de ser una parcela, una fracción, una operación" (Arte latinoamericano actual 12). Por otra parte, el arte pop suponía la claudicación definitiva de la pintura al asumir esta el lenguaje del comic, un lenguaje simple, basado en imágenes esquemáticas que confirmaban una aceptación de un modo de vida enajenante. Los artistas pop, 
al integrar en sus obras unas formas de representación de estas características, pese a su intención irónica, acababan convirtiéndose en amplificadores del modelo visual más característico de su tiempo, con todo lo que esto conllevaba. Este análisis -que era el propio de una apocalíptica, si seguimos la conocida antinomia propuesta por Umberto Eco entre apocalípticos e integrados en la sociedad de masas- adquiría una dimensión aún más alarmista cuando la autora abordaba la repercusión de este movimiento en América Latina. En este caso la contradicción estaba en el intento de adoptar semejantes formas de expresión artísticas, que remitían a una sociedad hiperdesarrollada, al ámbito social y cultural bien diferente: "el disparate es asumir como válida la señal de una sociedad de consumo altamente industrializada, dentro de sociedades que han sido calificadas por los sociólogos como 'arcaicas', 'feudales', semicoloniales o francamente coloniales" (20).

El planteamiento crítico de Pedrosa sobre este tema sigue un recorrido parecido al que acabamos de describir. El arte pop suponía para él una suerte de claudicación ante el fenómeno invasivo de la sociedad de masas. A diferencia del surrealismo, que levantó, con su capacidad de inventiva, una defensa ante esta realidad que se caracteriza por la presencia asfixiante de los objetos, el arte pop adoptaba una postura paradójica, que consistía en "criar ou manter o insólito na redundancia da comunicação de massa. A vulgaridade viril do comércio e da propaganda é o seu clima" (Crise o revolução do objeto 162). En otro texto suyo, escrito también a finales de los sesenta, Pedrosa, que calificaba a esta tendencia de anti arte, prefería llamar a los artistas que la practicaban técnicos de producción de masas, considerando que todos ellos se habían formado en el arte comercial o el mundo publicitario (Quinquilharia e Pop'Art 177). No obstante, en su momento el crítico brasileño consideró la objetividad de la obra pop, su despersonalización, como una muestra del nuevo rumbo que estaba tomando el arte contemporáneo, en el que se apreciaba un distanciamiento de la expresividad focalizada exclusivamente en el subjetivismo individual.

¿Qué se podía decir de la incidencia del pop en América Latina, o en Brasil, en su caso? Cuando tuvo ocasión de escribir sobre este tema, el crítico destacó las diferencias entre los artistas metropolitanos y los locales influido por esta tendencia; diferencias que no solamente se manifestaban en los límites de los recursos técnicos y mecánicos disponibles, también cabía hablar de la impronta de un componente cultural propio que alteraba la finalidad última de la imagen pop. Al referirse, por ejemplo a artistas como Gerchman o Antonio Dias, afirmaba que había en ellos "uma ingenuidade nativa, uma temática essencial, um modo de ser incoercível que não lhes dão a gratuidade necessária para abraçar, com vivacidade, brilho e naturalidade qualquer causa publicitária” (Do pop americano ao sertanejo Dias 368).

En la segunda edición de su libro La pintura del siglo $X X$, Romero Brest expone una visión histórica del pop internacional con interesantes matices interpretativos, centrados fundamentalmente en la imagen y su valoración en relación con el arte hasta esos momentos conocido. Se trataba de una opinión que dejaba atrás unas reticencias 
iniciales coincidentes con las mantenidas por Clement Greenberg, que consideraba el pop un fenómeno kitsch ${ }^{8}$. Según el crítico argentino, las imágenes pop respondían a una "naturaleza ontológica diferente", presentan "otro modo de ser que el de las tradicionales", pues "son apariencias sobre la base de una cosidad del contenido y de la forma, fuera del contexto histórico" (421). Podía decirse por tanto que estábamos ante un fenómeno de despersonalización cuyo origen estaba en gran medida en la influencia de las imágenes proveniente de los medios de masa, aunque esto no fuera del todo cierto en todos los artistas, como aclara el crítico. Habría que plantear también en qué medida la figuración pop había supuesto un retroceso a la pintura tradicional por la recuperación de la representación ${ }^{9}$ o, por el contrario, al sustentarse en la imagen despersonalizada, cabría hablar de una alternativa plástica en avanzada. Lo cierto es que "al representar esas cosas comunes que 'están ahí, sus imágenes desmantelan fina e irónicamente la actitud creadora en vez del organismo plástico" (423), algo que implicaba un cambio de calado en los fundamentos en los que se había basado el arte moderno hasta ese momento. Por otro lado, nada había en este texto, escrito con una cierta distancia temporal, de las reservas mostradas hacia esta tendencia por Traba y Pedrosa. En su momento Romero Brest reconoció la poca repercusión del pop norteamericano en América Latina, concretamente en la Argentina, pero en ningún momento cuestionó sus posibilidades como lenguaje artístico por razones de tipo político o social.

\section{Objetualismo, happening y otras experiencias}

Hay una enorme discrepancia entre el pensamiento crítico de Marta Traba y el de Romero Brest y Mário Pedrosa con respecto a las nuevas experiencias que cuestionan el rol tradicional del artista y el estatus del objeto artístico en los sesenta. Es este uno de los temas más recurrentes en los textos del crítico brasileño, que apostaba por un arte participativo que buscaba implicar al espectador, romper con su pasividad contemplativa, alejarlo, como él decía, "de seu indiferentismo plurissensorial e corpóreo, de seu neutralismo moral e cultural" (Do porco empalhado ou os criterios da crítica 235). En este sentido, las críticas suyas de estos años inciden frecuentemente en la importancia del trabajo de artistas brasileños como Lygia Clark, Oiticica y otros que superan esa "solemne soledad" tan característica de las obras de la vanguardia abstracta histórica, en su búsqueda por establecer una relación nueva entre artista y sujeto. Se trataba de valorar la importancia del cuerpo en la experiencia estética. Como explica a propósito del arte ambiental de Oiticica, la obra del artista "passou da expêriencia

8 Vid. Giunta, Andrea. «Jorge Romero Brest and the Coordinates of Aesthetic Modernism in Latin America». Art Journal 4 (2005) 91. Para la historiadora argentina, la reconsideración posterior de Romero Brest sobre el pop se entiende en el contexto de la influencia de la filosofía existencialista.

9 La pregunta resultaba más pertinente para Romero Brest cuando, como había ocurrido con la Bienal de São Paulo de 1964, se asociaban las obras pop con las de un artista como Edward Hopper. 
visual, em su pureza, para uma expêriencia de tato, de movimento, da fruição sensual dos materiais, em que o corpo inteiro, antes resumido na aristocracia distante do visual, entra como fonte total de sensorialidade" (Arte ambiental, arte posmoderna, Helio Oiticica 357). Es en este contexto cuando Pedrosa propone su concepto de arte posmoderno, entendiendo por tal aquel en el que se procede a la superación de los valores exclusivamente plásticos, que son absorbidos "na plasticidade das estruturas perceptivas e situacionais” (357). Se entraba así, en palabras suyas, en un ciclo nuevo que dejaba de ser exclusivamente artístico y se extendía al campo amplio de lo cultural. La crítica del último tercio del siglo XX, aquella que irrumpe con la crisis de la modernidad, hizo suyo, como se sabe, el mismo término, pero desde unos presupuestos de mayor complejidad y de naturaleza sistémica.

Al comentar el manifiesto "Contra la internacional de la mediocridad", de Pierre Restany, a Pedrosa le interesaba destacar cómo el crítico francés insistía en esta nueva visión del arte, planteando de una manera radical una alternativa artística en la que la actividad del artista sobrepasaba el papel que se le había atribuido secularmente. Por el contrario, se proponía ahora que volcase sus energías en manifestaciones colectivas de tipo festivo, potenciando los aspectos lúdicos mediante un ejercicio de experimentación plenamente libre en que la reproducción mecánica de la obra fuera siempre factible. La lectura del manifiesto de Restany le llevaba a concluir a Pedrosa que muy probablemente este fuera demasiado optimista en el planteamiento de sus objetivos, puesto que estos se defendían en un marco económico y social que no discutía la propiedad privada de los medios de producción y el consumismo imperante. Difícilmente se podía llegar a pensar que la sociedad contemporánea con esas condiciones pudiera conseguir algo que "nas sociedades culturais primitivas, foi decisivo para a sua conservação e florescimento; as manifestações do sagrado entre as quais a Arte sem dúvida era a mais profunda, comunicativa e integradora" (O manifestó pela arte total de Pierre Restany 240).

También la crítica de Restany es objeto de comentario por parte de Marta Traba, pero en su caso no hay ningún matiz que indique contemporización alguna hacia una propuesta que es vista con recelo desde posiciones ya conocidas, que suponían un cuestionamiento total de todas las manifestaciones artísticas provenientes de los centros del arte internacional, también, como es lógico pensar, de los planteamientos teóricos que las sustentaban. Comentaba Traba que las ideas de Restany sobre el artejuego, fenómeno que ella relaciona con el arte pop, el objetualismo y los ambientes, se caracterizaban por su artificialidad y su vinculación a los sistemas alienantes, que necesitaban de la distracción con el fin de olvidar los problemas que generan las crisis. Por el contrario, "el aporte que Latinoamérica puede dar a lo lúdico radica, justamente, en su diversa naturaleza, en su interpenetración con elementos míticos reales, con contextos mágicos que afloran de las culturas andinas, centroamericanas o caribes de donde provienen" (Dos décadas vulnerables en las artes plásticas latinoamericanas 1950-1970 45). 
Como expusimos anteriormente, la posición definida y polémica de Marta Traba se extendió también a las actividades dirigidas por Jorge Romero Brest en el bonaerense Centro de Artes Visuales del Instituto Torcuato di Tella. Traba relaciona experiencias como "La Menesunda”, de Marta Minujín y Santantonín con el "happening", sobre el que vierte un juicio que no deja lugar a dudas: "el gran propósito del 'happening', como fue el de convertir toda la vida humana en una verdadera obra de arte fracasó por completo al no poder llegar, en el mejor de los casos, más que a una terapia colectiva”. En el caso de los espectáculos del Di Tella, la cosa no iba "más allá de un pequeño circo provincial" (143).

En Jorge Romero Brest conviene distinguir entre las reflexiones teóricas con relación a las actividades dirigidas por él en el Instituto Torcuato di Tella y aquellas otras que superan los límites de las experiencias concretas y se incorporan a la polémica del arte contemporáneo en su dimensión más universal. En su libro El arte en la Argentina, el relato de las iniciativas llevadas a cabo en la institución bonaerense respondía a hechos muy recientes y revelaban una gran coherencia ideológica en sus interpretaciones. Romero Brest habla de "happenings", "arte de los medios" y "experiencias" para referirse a las distintas actividades desarrolladas. Lo que aquí nos interesa destacar es que todas ellas confirman el descrédito del objeto artístico tradicional, y, en su caso más extremo, en las denominadas "experiencias", se renuncia incluso a la obra creada a favor de una fase previa de elaboración de materiales en la que, en términos del crítico, se ejerce "la conciencia de imaginar" (90). Romero Brest tuvo la oportunidad de teorizar desde esta posición de radicalismo estético en su libro Nuevas modalidades del arte. Todo el argumentario expuesto en este libro no persigue otro fin que el de justificar la necesidad de una nueva postura artística que esté en consonancia con una situación cultural en transformación en la que la implantación de los medios de comunicación se vuelve determinante. El crítico argentino se preguntaba en este libro qué sentido tenían las artes tradicionales como la pintura y la escultura en ese contexto, cuando eran artes que marcaban una distancia entre el sujeto y el objeto creado: "Estamos creando una cultura popular, con medios de comunicación masivos, aun los que forman parte de la élite (...) La pintura no puede competir con esos medios porque los cuadros ponen distancia: ahí está el cuadro, aquí estoy yo, del mismo modo que cuando leo a Kant, allí están sus ideas y aquí estoy yo" (13). Se trataba de una visión optimista en tanto las transformaciones del arte se entendían en un marco de también transformaciones sociales y culturales que podían relacionarse fácilmente con la efervescencia revolucionaria del 68. Sin embargo, como deja ver en El arte en la Argentina, había una situación de fricción cuando se asociaba la experimentación artística con una intencionalidad política o de crítica social, algo que el crítico consideraba no conveniente, en la medida en que el campo de la creación artística, aun considerando transformaciones de tanta importancia, debía preservar su plena autonomía. No obstante, como en su momento señaló Marta Traba en sus Dos décadas vulnerables (144), Romero Brest no negó nunca la existencia de una ligazón 
entre las actividades por él impulsadas y el desarrollismo económico argentino de ese momento, como de igual manera las últimas experiencias artísticas en los Estados Unidos estaban directamente relacionadas con su impresionante expansión económica. Habría que concluir, por tanto, que había una contradicción de base en el discurso crítico de Romero Brest, toda vez que sus propuestas experimentales mantenían una dependencia de un modelo económico de cuyos beneficios cabía esperar lo mejor, pero cuyos desajustes y problemas no encontraba la posibilidad de una expresión abierta a través de la creación.

\section{Referencias}

Pedrosa, Mário. «Bienal, panorama do mundo» (1954). Dimensões da arte. Río de Janeiro: Ministério da Educação e Cultura, 1964. 183-194. Medio impreso.

---. «Da abstração a auto-expressão». Mundo, homen, arte em crise. São Paulo: Perspectiva, 1986. 35-47. Medio impreso.

---. «Vicisitudes del artista soviético». Mundo, homen, arte em crise. São Paulo: Perspectiva, 1986. 93-98. Medio impreso.

---. «Crise o revolução do objeto». Mundo, homen, arte em crise. São Paulo: Perspectiva, 1986. 159-162. Medio impreso.

---. «Quinquilharia e Pop’Art». Mundo, homen, arte em crise. São Paulo: Perspectiva, 1986. 175-179. Medio impreso.

---. «Do porco empalhado ou os criterios da crítica». Mundo, homen, arte em crise. São Paulo: Perspectiva, 1986. 231-236. Medio impreso.

---. «O manifesto pela arte total de Pierre Restany». Mundo, homen, arte em crise. São Paulo: Perspectiva, 1986. 237-240. Medio impreso.

---. «Arte e revolução». Mundo, homen, arte em crise. São Paulo: Perspectiva, 1986. 245-248. Medio impreso.

---. «O Brasil na IV Bienal. Pintura brasileira e gosto internacional». Arantes, Otilia (org.). Mário Pedrosa: Acadêmicos e modernos 3. Editora de la Universidad de São Paulo, 1998. 279-282. Medio impreso.

---. «Arte ambiental, arte posmoderna, Helio Oiticica». Arantes, Otilia (org.). Mário Pedrosa: Acadêmicos e modernos 3. Editora de la Universidad de São Paulo, 1998. 355-360. Medio impreso.

---. «Do pop americano ao sertanejo Dias». Arantes, Otilia (org.). Mário Pedrosa: Acadêmicos e modernos 3. Editora de la Universidad de São Paulo, 1998. 367371. Medio impreso.

---. «Burri, ou a antipintura vitoriosa». Arantes, Otilia (org.). Mário Pedrosa: Modernidade cá e lá 4. Editora de la Universidad de São Paulo, 2000. 247-254. Medio impreso. 
Romero Brest, Jorge. «Um grupo de jovens pintores e escultores argentinos». Grupo de Artistas Modernos Argentinos. Río de Janeiro: Museo de Arte Moderna, 1953. Medio impreso.

---. ¿Qué es el arte abstracto? Buenos Aires: Columba, 1953. 59. Medio impreso. Medio impreso.

---.«Diálogo sobre el arte abstracto y el arte concreto». Saber Vivir 108 (1954). 20-24.

---. «El arte informal». Del Arte V (1961). 9. Medio impreso.

---. Deira, Macció, Noé, de la Vega. Buenos Aires: Museo Nacional de Bellas Artes, 1963. Medio impreso.

---. El arte en la Argentina. Buenos Aires: Paidós, 1969. Medio impreso.

---. Nuevas modalidades del arte. Buenos Aires: Ediciones Culturales Olivetti, 1970. Medio impreso.

---. La pintura del siglo XX (1900-1974). México: FCE, 1978. Medio impreso.

Traba, Marta. La pintura nueva en Latinoamérica. Bogotá: Ediciones Librería Central, 1961. Medio impreso.

---. Los cuatros monstruos cardinales. México: Ediciones Era, 1965. Medio impreso.

--- Arte latinoamericano actual. Caracas: Biblioteca de la Universidad Central, 1972. Medio impreso

---. Dos décadas vulnerables en las artes plásticas latinoamericanas (1950-1970). México: Siglo XXI editores, 1973. Medio impreso.

Recibido: 21 septiembre 2013 Aceptado: 27 marzo 2014 